\title{
HÅBETS F/ELDE?
}

\section{Fortryllelse og universel skolegang i Uganda og Tanzania}

\author{
LOTTE MEINERT OG METTE KØLNER
}

Håbet og troen på, at skoling og uddannelse kan gøre verden bedre, er praktisk taget universel. „Uddannelse for alle” er i disse årtier gjort til en global højprioritet, der figurerer som nummer to på listen over FN's millenniummål efter det første uomgængelige mål om at udrydde ekstrem fattigdom og sult. Millenniummålet for uddannelse lyder: „Inden år 2015 skal alle børn, piger og drenge, have mulighed for at færdiggøre en grundskoleuddannelse“ (http://www.2015.dk). Målet er et ekko af Jomtien-deklarationen fra 1990, som ligeledes promoverede „education for all“". Internationale donorer, nationale regeringer, ngo'er, religiøse og andre organisationer investerer massivt $\mathrm{i}$, at børn og unge får mulighed for at komme i skole og få en uddannelse. Familier investerer penge, tid og kræfter, mens børn og unge selv gør den største af alle indsatser for at komme i og igennem skolen. Aktører og institutioner på mange forskellige niveauer, og i vidt forskellige kontekster, er således dybt engagerede i kampen for og troen på skolegang. Det kan derfor synes omsonst igen at rejse det kritiske spørgsmål, som den østrigske filosof Ivan Illich gjorde det med værket Deschooling Society i 1971, om skolegang overhovedet er godt for mennesker og samfund. Alligevel vil vi i denne artikel forholde os kritiske til den globale konsensus og undersøge det løfte, vi tilsyneladende alle mener, skoling indeholder.

Tankegangen bag millenniummålet for uddannelse er umiddelbart forførende, fordi den indeholder et potent miks af fornuft, retfærdighed og håb. Men succeskriteriet synes blot at være, at alle børn skal igennem skoleinstitutionen, så indskrivningstallene globalt bliver så høje som muligt. Deri ligger en antagelse om, at uddannelse er et sine qua non i forhold til udvikling, uanset hvilken kontekst den indgår i. De velkendte og kritiserede oplysnings- og modernitetsideer om, at uddannelse automatisk fører til økonomisk vækst og dermed løsning af alverdens fattigdomsproblemer, skinner tydeligt igennem denne type tænkning, 
hvor der ikke refereres til den underliggende betydning af uddannelse eller de faktiske konsekvenser af at gå i skole.

Ikke kun på det politiske niveau, men også på det individuelle plan bærer skolegang og uddannelse en slags fortryllelse med sig, fordi det indeholder et løfte om forbedring i fremtiden. Med skolehistorier fra Uganda og Tanzania forsøger vi i artiklen at indkredse den fortryllende magt, der omgiver skolegang, og som virker forførende og lokker folk i, hvad der synes at være en moralsk fælde. Samtidig viser vi med historierne, at uddannelse for nogle skoleelever alligevel har en stor betydning, men at den er en anden end den, arkitekterne bag skoleprogrammerne, og ofte også eleverne selv, havde forestillet sig. Vi forsøger dermed at belyse de sociale dynamikker, der sættes i gang, når eftertiden ikke kan indfri de løfter og håb, som børn og unge begynder at tro på i løbet af skolegangen.

Et væsentligt argument i artiklen er, at den fortryllelse, der omgærder uddannelse, ikke er statisk og totalt forblindende, men dynamisk som et pendul, der svinger mellem tro og dyb mistro. Troen på uddannelse bølger således frem og tilbage over tid, gennem skiftende politiske diskurser, historiske epoker og i enkelte individers og familiers liv, afhængigt af konkrete erfaringer, muligheder og strukturelle begrænsninger i nuet. Fortryllelses- og affortryllelsesdynamikken er således en kontinuerlig og omstridt social proces, som tager form og indhold, alt efter hvornår skolegangens betydning undersøges, hvem der spørges, og ikke mindst hvor i deres livsforløb disse befinder sig. Med artiklen søger vi netop at indfange den ambivalens og de tilsyneladende modsigelser, der lokalt omgærder uddannelse, for dermed at tegne et nuanceret billede af den på én gang både magiske og håbløse skolegang i Østafrika.

Feltarbejdet, som danner baggrund for disse overvejelser, har fundet sted $\mathrm{i}$ henholdsvis Uganda og Tanzania. Mette Kølner har lavet feltarbejde i det nordvestlige Tanzania i 2003 om sammenhængen mellem modernitet, køn og uddannelse. Feltarbejdet foregik både på grund- og sekundærskoler ${ }^{1}$ og strakte sig over et halvt år. Lotte Meinert har lavet feltarbejde i det østlige Uganda igennem det seneste årti. Det første års feltarbejde foregik i 1997-98 blandt børn og unge i grundskolen og fokuserede på sammenhængen mellem skolegang og sundhed. I det efterfølgende årti er syv af børnene fra seks familier blevet besøgt og interviewet cirka hvert halve år.

Vi præsenterer i artiklen enkelte af de unge, vi har fulgt i løbet af årene, men trækker også på viden fra andre cases og andet materiale. Hensigten med sammenstillingen af materialet fra Uganda og Tanzania er dels at beskrive nogle generelle tendenser i de sociale dynamikker omkring uddannelse i Østafrika, dels at få øje på, hvordan forskellige historiske og politiske forhold i de to nationer spiller ind på udviklingen og betydningen af skolegang. 


\section{Betydningen af skolegang i historisk perspektiv}

Den historiske sammenvævning af uddannelse, modernitet, velstand, religion og stat er central for at begribe den fortsatte entusiasme og tro på uddannelse i Østafrika. De prækoloniale uddannelsestraditioner, som primært bestod i historiefortælling og praktiske læremesterforhold, blev i høj grad ignoreret og nedvurderet af missionærerne, da de ankom til Østafrika. Derfor starter historieskrivningen omkring uddannelse typisk med indførelsen af skoler i forbindelse med missionsaktiviteter i slutningen af 1800 -tallet. ${ }^{2}$ Kirken og skolen var én sammenhængende institution, og i Uganda besad missionærerne uddannelsesmonopolet til langt ind i det næste århundrede (Hansen 1984:224ff.). I Tanzania blev de missionsskoler, tyskerne efterlod til briterne, dog allerede i 1927 afløst af en mere sekulær type skole (Austen 1968:146). I begge lande forblev religion og skoling imidlertid tæt forbundne i det moderne omvendelses- og oplysningsprojekt, der skulle gøre de tilbagestående hedninge til moderne, kristne medborgere i nationalstaten. Skolegang var i denne periode forbeholdt en lille elite, som efter endt uddannelse fik gode job i den koloniale administration, og her blev kimen lagt til den stadige forventning om en automatisk sammenhæng mellem uddannelse, lønnet arbejde og en vis levestandard. Efter Ugandas politiske uafhængighed i 1962 bragte regeringen alle skoler under statens kontrol, mens det i Tanzania først skete i 1966, og i de følgende årtier blev der bygget mange nye skoler, hvilket øgede adgangen for den bredere befolkning. I disse år lagde regeringerne i de to lande særlig vægt på uddannelse som et moderne nationalt projekt. Skolegang blev en synlig og aktiv måde at være moderne medborger på. Parallelt hermed faldt kvaliteten af undervisningen imidlertid, og kandidater kunne ikke længere regne med at få job efter endt uddannelse. Arven fra det koloniale uddannelsessystem bestod blandt andet $i$ en tendens til at producere jobsøgere snarere end jobskabere, hvilket medvirkede til beskæftigelsesproblemet (se Dore 1976).

Skoleinstitutionens tidlige historie i Tanzania og Uganda ligner på mange punkter hinanden, men der er dog forskelle, blandt andet i forhold til indførelsen af „Universal Primary Education“ (UPE), hvorfor vi i det følgende beskriver de to lande for sig.

\section{Tanzania}

Tankerne omkring ,uddannelse for alle“ $i$ Afrika har på mange måder sine rødder i Tanzania. Således var ideerne om UPE allerede at finde i Tanzania i starten af 1970'erne - længe før diverse deklarationer stadfæstede uddannelse som mål for hele verden. I forbindelse med landets selvstændighed i 1961 udtalte daværende 
præsident Nyerere, at Tanzania ville tænde et lys på Mount Kilimanjaro, der skulle skinne ud over landets grænser til resten af Afrika som et symbol på håb, frihed og udvikling - en vision, der i Tanzania i særlig grad blev bundet op på netop uddannelse. Tanzania skabte i disse år således en uddannelsespolitik, der kom til at fungere som skabelon for UPE i store dele af det øvrige Østafrika.

UPE var i høj grad produktet af Nyereres tanker omkring udvikling. Heri figurerede en afsluttende grunduddannelse for alle Tanzanias børn på den mest fremtrædende plads som det altafgørende våben i kampen mod fattigdom, sygdom og uvidenhed og ikke mindst som et konkret værktøj til at skabe national enhed. Med andre ord skulle skolen skabe en bestemt type medborgere, der sikrede økonomisk vækst for landet såvel som social, politisk og kulturel udvikling. Det moralske ansvar for nationens velbefindende blev dermed gjort til et personligt anliggende for den enkelte tanzanier, som forventedes at blive uddannet for at opnå status som en værdig, moderne medborger. Beslutningen om at indføre obligatorisk, gratis skolegang blev dog først implementeret i 1977. Tiltaget fik indledningsvis stor opbakning blandt tanzanierne, der strømmede til skolerne i håbet om adgang til højt betalte job og et bedre liv end dét, de kunne opnå som bønder i landsbyerne. Den umiddelbare effekt af den gratis skolegang var, at procentdelen af indskrevne i skolealderen steg til over 90 procent (Vilby 2005). Væksten i antallet af elever blev dog ikke mødt med tilsvarende vækst $i$ antal nyopførte skoler eller uddannede lærere, og kimen til den nuværende utilfredshed med kvaliteten af undervisningen i grundskolen blev for mange forældre lagt allerede her.

Indledningsvis blev UPE finansieret af den tanzaniske stat alene, men byrden blev for stor, da 80 'ernes krise ramte Tanzania, der måtte optage udenlandske lån og blev underlagt Verdensbankens strukturelle tilpasningskrav. I 1984 indførte regeringen derfor en, i teorien frivillig, men i realiteten tvungen, indbetaling til en såkaldt ,udviklingsfond“, der skulle hjælpe skolerne ud af krisen. Selv om der ikke var tale om en formel indførelse af skolepenge, blev tiltaget alligevel startskuddet til en bevægelse væk fra den gratis uddannelse for alle over mod en privatisering af uddannelsessektoren, der i stedet blev for en mindre gruppe. Denne privatisering kunne aflæses i indskrivningstallene for grundskolen, der stagnerede op gennem slutningen af firserne for derefter at dale helt ned til 66 procent i 1996 (Lasibille et al. 2000:4), efter at skolepenge igen var blevet formelt introduceret i 1995. Først i slutningen af 2001 bukkede en modvillig tanzanisk regering under for Verdensbanken og udenlandske donorers pres og gjorde grundskolen gratis og dermed i praksis næsten universel igen. I dag angiver regeringen, at indskrivningsprocenten i de tanzaniske grundskoler i 2008 lå på 97,2 procent, hvilket antyder, at Tanzania er godt på vej mod at nå millen- 
niummålet og dermed kunne være en afrikansk succeshistorie. Dog påstår kritikere, at det reelle indskrivningstal ligger tættere på 77 procent, og at kun omkring 20 procent vil færdiggøre grundskolen (Shephard 2009).

Selv om tallene for indskrivning - ligesom kritikken af UPE - har været fluktuerende, er holdningerne dog nogenlunde de samme i dag som dengang. Ikke mindst fra politisk side ses grundskoling stadig som en fundamental borgerrettighed og pligt, noget, man bør færdiggøre for ikke at udgøre en fare for sig selv, sin familie og på et højere plan selve nationens velbefindende (http://www.moe.go.tz/ policy_issues.html). Den moralske inklination til at give børn en uddannelse forsvandt således ikke på noget tidspunkt i de perioder, UPE var skolepengedrevet, men blev om muligt mere påtrængende - ikke mindst for forældre, der havde svært ved at se andre veje ud af krisen end uddannelse.

\section{Uganda}

I Uganda brugte præsident Museveni „Free Primary Education“ som centralt valgløfte, da han stillede op til sin anden præsidentperiode i 1996. Folk betvivlede, at Museveni ville og kunne holde sit valgløfte, men han blev genvalgt, og med økonomisk opbakning fra en bred skare af udviklingsdonorer startede et universelt skoleprogram med stor hast i 1997. Introduktionen af det gratis skoleprogram var en epokegørende begivenhed i Ugandas uddannelsespolitik og skolehistorie. For første gang fik alle børn ${ }^{3}$ mellem 5 og 18 år en reel mulighed for at komme i skole. Før UPE-programmet startede, gik omkring 40 procent af børn i skolealderen i skole, mens tallet året efter lå på 95 procent.

Ressourcetilførslen til skolerne stod imidlertid ikke mål med tilstrømningen af børn. Som følge heraf var skolerne de næste år overfyldte, med alt for få lærere, klasseværelser, bøger og andre ressourcer. Mange skoler indførte uformelle skolepenge, som blev brugt til at købe nødvendige undervisningsmaterialer og betale lærerne. Hovedparten af børnene gik i de næste år en eller flere klasser om, og i 2007 - ti år efter uddannelsesprogrammets indførelse - var igen kun cirka 50 procent af børn i skolealderen indskrevet i skolen. Dels på grund af de uformelle skolepenge, som mange ikke kunne eller ville betale, og dels fordi der på mange skoler reelt ikke foregik megen skoling.

På trods af nedgangen i tilstrømningen til skolen blev den universelle skolepolitik en kritisk begivenhed ${ }^{4}$ i Uganda, fordi den slog fast, at børn pr. kronologisk definition (over 5 år) og pr. lov skulle være i skole. Skolepolitikken etablerede således et nationalt ideal om, at barndom skal indeholde skolegang, og at forældreskab inkluderer pligten til at sørge for dette. UPE-programmet gjorde samtidig staten synlig i lokalsamfund på en måde, den ikke havde været før. 
Nationalflaget, som hejstes hver morgen, og børn i skoleuniform, der sang nationalsang, blev en del af hverdagen i de fleste landsbyer, og dermed blev skolen den statslige institution med den største nationale udbredelse i Uganda. End ikke militæret, distriktsmyndigheder eller sundhedsvæsnet nød en lignende institutionel synlighed og udbredelse. At være skoleelev blev således en almindelig, tydelig og anerkendt måde at være medborger i nationalstaten på.

Før UPE var det primært den økonomisk bedst stillede halvdel af befolkningen, der sendte deres børn i skole, fordi de havde råd til at betale skolepengene. Det havde de fattige ikke og var derfor undtaget og undskyldt for ikke at kunne deltage i dette nationale medborgerprojekt. Men da det med UPE officielt blev gratis at sende børn i skole, var der ingen undskyldning. At skolerne i realiteten krævede - selv om de officielt ikke måtte - at børnene kom i uniform, havde bøger med, og at forældrene betalte de uformelle skolepenge, betød, at en stor del af befolkningen alligevel ikke havde råd til at sende deres børn i skole. Politikere fremhævede i medierne, at „forældre gemte børnene væk for staten“, fordi de ville bruge dem som arbejdskraft derhjemme, og at forældre berøvede børn en chance for at gå i skole og dermed også løftet om en lys fremtid. Begge begrundelser spillede sikkert en rolle, når forældre ikke sendte deres børn i skole: Det kostede penge, og mange havde brug for børnenes hjælp i hjemmet. I $2007 \mathrm{blev}$ der i parlamentet fremsat forslag om, at forældre, der ikke sendte deres børn i skole, skulle kunne anholdes og straffes.

Med indførelsen af den obligatoriske skolegang fremmede man således både i Tanzania og Uganda en bestemt type subjektivitet og måde at være borger i staten på, hvor det moralske ansvar for nationens velbefindende blev gjort til et individuelt anliggende. Både for børn og forældre. Denne subjektivitet indeholder for børnene en teleologisk idé om en velafgrænset livsbane, der går fra grundskole mod videre uddannelse og derefter ender med et lønnet job, som medfører social og økonomisk opadgående mobilitet. Individers uddannede livsbaner forventes således at bidrage helt konkret til statens økonomiske og demokratiske udvikling. Og selv om disse livsbaner forløber anderledes end idealet og for de fleste ikke nødvendigvis ender med job, velstand og bidrag til nationens udvikling, lever drømmen om denne subjektivitet og sammenhæng videre og giver kraft til skolens fortryllende magt.

I det følgende præsenterer vi to unge drenge - Ochom fra Uganda og Deus fra Tanzania, som illustrerer den sociale og ambivalente dynamik, der udspiller sig omkring uddannelse. 


\section{Ochom - Uganda}

Ochom var 12 år, da UPE startede i 1997. Han boede hos sine bedsteforældre, sin onkel og tante og deres børn i et fattigt hushold på en meget lille jordlod i udkanten af landsbyen Asinge i det østlige Uganda. Ligesom mange andre familier i området kæmpede Ochoms familie dagligt for at producere mad nok til at kunne overleve og for at skaffe penge til medicin, når familiemedlemmer var syge. Familien var dybt afhængig af, at bedrestillede dele af slægten hjalp til i sultperioder og andre kriser. Morfaren, som var en tynd, indtørret mand, fortalte med et kraftfyldt blik, der gjorde, at man ikke umiddelbart spurgte videre, at Ochoms far ,ikke var dem bekendt“. Det viste sig at betyde, at den mand, som stort set alle i landsbyen mente var Ochoms far, ikke ville anerkende Ochom som sin søn. Ochoms mor forsvandt, måske som prostitueret, til et nabodistrikt, mens Ochom stadig var lille.

Ochoms bedsteforældre havde ikke gået i skole. Morfaren var født i 1937 og voksede op som kvægdreng i den tid, hvor skolegang var forbeholdt de få. „Dengang kunne børn vokse op uforstyrret. Vi blev ikke straffet, men arbejdede hjemme med at lave mad, dyrke jorden, vaske op, gå ærinder", sagde mormoren. Ochoms mor havde gået et par år i skole, men var droppet ud tidligt, da familien ikke havde råd til at betale skolepenge. Ochoms formodede far havde gået både i grund- og sekundær skole og havde uddannet sig til tolder. Da Ochom boede hos bedsteforældrene, som ikke havde nogle penge, havde familien ikke regnet med, at Ochom skulle i skole, men da UPE-programmet blev lanceret i 1997, sendte bedsteforældrene ham af sted. Ochom blev registreret til 1. klasse på Asinge Skole og begyndte at gå der. Dog uden skoleuniform. Da der ikke var klasselokaler til alle, samlede lærerne grupper på cirka 100 børn under store træer og med tavle og kridt, og så forsøgte de at undervise. Efter et par måneder fortalte mormoren, at skolen havde bedt hende om at købe en skoleuniform til Ochom, og det havde hun ikke råd til. Derfor blev Ochom smidt ud af skolen. Men ifølge den nye skolelov kunne børn ikke afvises på grund af manglende uniform. I skolen sagde lærerne, at Ochom var uartig og havde slået en anden dreng. Lærerne mente, at problemet var bedsteforældrene, som var uuddannede og ikke havde opdraget ham ordentligt. Ochom selv fortalte, at den anden dreng havde slået og drillet ham, fordi han ingen uniform og forældre havde. Efter et par måneder derhjemme kom Ochom og spurgte om penge til at købe en skoleuniform, så han kunne starte i skole igen, fordi han ville have en uddannelse og være chauffør, når han blev stor. Skoleuniformen blev købt, og Ochom startede igen i skolen. I løbet af de næste otte år droppede Ochom ud og ind af skolen, var nødt til at gå en klasse om, men endte med at bestå afgangseksamen. 
Da Ochoms morfar døde, solgte onklen jorden, og familien flyttede til nabodistriktet Iganga. I mellemtiden var Ochom blevet bevidst om, at han ikke havde adgang til jord og intet sted at bygge et hjem, hvis han ingen far havde, og hvis onklen flyttede. Efter forgæves forsøg på at få sin far i tale kontaktede Ochom sin farfar, som var bonde og tidligere høvding i landsbyen, og farfaren gav Ochom et lille stykke jord, hvor han kunne bygge et hus. Men Ochoms nye stedmor var jaloux og bekymret over sine egne sønners arvestatus i familien, nu da den førstefødte søn, som tilmed var under uddannelse, havde gjort sin entre i familien. Så stedmoren stak ild på Ochoms hus og truede ham på livet, hvis han vendte tilbage. Farfaren og andre familiemedlemmer forsøgte at forhandle, men både faren og stedmoren var uforsonlige og slog fast, at de aldrig ville anerkende Ochom som søn af familien. Ochom var ulykkelig, men pragmatisk og ræsonnerede: „Så er min eneste chance uddannelse." Han kom ind på den lokale sekundærskole, men det var tydeligt, at Ochom havde det svært. Dertil fandt han det ikke let at bo i nærheden af faren og stedmoren, så Ochom flyttede ind hos sin mormor og onkel i nabodistriktet og begyndte på en mekanikerskole. I 2008 blev han færdig med sin mekanikeruddannelse og fik kørekort. Dog sagde han med nogen ærgrelse:

Jeg er nået længere med uddannelse, end nogen havde drømt om ... Men hvis jeg virkelig skal lære at reparere og køre biler, skal jeg have et job hos en mekaniker, og vi kender ingen ... Der er ikke arbejde at få, hvis man ikke kender nogen. Så den bedste udvej er nok at købe mig et stykke jord, som jeg kan dyrke og leve af.

\section{Deus - Tanzania}

Deus var en sky og tilbageholdende dreng, der for det meste holdt sig for sig selv i pauserne mellem timerne på Sengerema Secondary. Når de andre drenge luskede om bag sovesalene for at høre musik på deres radioer, råbe efter pigerne på gangen eller diskutere højlydt i diskussionsklubberne, sad Deus for sig selv i klasselokalet og kiggede ud ad vinduet eller gik rundt i den omkringliggende skov med en af sine få venner. Deus var 16 år og kostskoleelev på Sengerema Secondary og på nippet til at droppe ud.

Deus var vokset op under trange kår i en fiskerlandsby ved Lake Victoria $\mathrm{i}$ Nordtanzania med sin familie. Mens han endnu gik i grundskole, mistede han sine tre søskende på grund af sygdom, og i 2001 døde hans mor. Deus' far overlod ham til morfaren, der ernærede sig som bonde i en nærliggende landsby i det tilstødende distrikt Missungwi. Hvor Deus' far var taget hen, vidste Deus ikke, og resten af familien havde han ikke haft kontakt med siden morens død. Morfaren var med andre ord den eneste familie, Deus havde tilbage, og nu var han blevet syg og kunne ikke længere passe jorden og havde svært ved at betale for Deus' 
uddannelse. Deus planlagde derfor at droppe ud af skolen, forlade distriktshovedstaden Sengerema og flytte tilbage til landet for at blive bonde, så han kunne passe sin morfar - en beslutning, Deus stod aldeles alene om at se det fornuftige i. Deus fortalte, at han for første gang i sit liv fik tæsk af morfaren, da han luftede tanken om at droppe ud af skolen:

Han var meget gal. Han sagde: 'Hvorfor håner du mig med den beslutning? Hvorfor? Du kan ikke spise de penge, jeg har betalt for din uddannelse!' Han var meget bekymret for, hvad folk ville sige. Måske var det derfor, han slog mig.

Morfaren havde ikke selv fået en uddannelse, hverken grundskole eller sekundær skole, men havde sat en stor ære i at sende Deus' mor i skole tilbage i 70'erne. Moren droppede ud af grundskolen i 4. klasse, men fik alligevel et job som sundhedsassistent på en landklinik. I dag, mente Deus, kunne den slags ikke lade sig gøre blot med en grundskoleeksamen. Derfor kunne han lige så godt blive bonde, ræsonnerede han. Deus' resignation og umiddelbare indifference over at måtte droppe ud af skolen virkede umiddelbart besynderlig og stod i stærk kontrast til hans læreres hånlige kommentarer dertil, morfarens protester og ikke mindst hans medstuderendes rysten på hovedet. Men det blev i højere grad forståeligt efter at have hørt om hans problemer i skolen: Deus kunne ikke længere følge med nu, hvor al undervisning foregik på engelsk. End ikke sine egne noter i notesbøgerne kunne Deus forstå, eftersom de var afskrivninger af lærerens engelske notater. Derudover var de fleste af Deus' venner kammerater fra grundskolen, som ikke havde formået at komme videre til sekundærskole, og det blev han jævnligt hånet for af de øvrige elever.

„Det var min familie, der pressede mig til at gå på Secondary,“ sagde Deus. „Ikke mig. Det var særligt min mor. Hun ville have, at jeg skulle blive ...'nogen'. Hun ville ikke have, at jeg skulle få et hårdt liv." Men Deus havde ikke længere lyst til at gå i skole, og omstændighederne gjorde, at han reelt heller ikke længere havde muligheden for at gøre, som hans familie havde ønsket. Deus var klar over, at han dermed fraskrev sig muligheden for det „moderne“ liv, skolen opstillede som det optimale fremtidsscenarie. Ifølge Deus var der dog noget positivt ved at stige af uddannelsesræset, nemlig dét, at han måske ikke ville blive opsøgt af familie, venner og naboer, der alle ville have del i hans succes, som det ville være tilfældet, hvis han blev færdig med sekundær skole.

Når de hører, du er færdig, så kommer de løbende helt fra Mtwara og Kigoma for at få noget fra dig. Selv om du ikke har et job, ikke har penge, så tror de, at det får du ... De vil endda spise murstenene i dit hus. Sådan noget kan ruinere dig. Men hvis du er bonde ... så lader de dig være. 
Hvor Deus således valgte at fokusere på de muligheder, et liv som bonde kunne afkaste, var hans omgangskreds anderledes hurtige til at fælde dom og udpege de faldgruber, der ventede en uuddannet uden for skolens mure. Deus endte med at droppe ud af skolen, hvilket på skolen kun affødte rysten på hovedet og kommentarer som denne fra en lærer: „Nu tager han tilbage til landsbyen, og hvad sker der så? Det kan jeg fortælle dig: Ingenting! Han er tabt. Der er ingen fremtid.“

\section{Fælden og fortryllelsen}

Der er flere aspekter og problematikker i de to unge drenges skoleforløb, men i dette tilfælde anvender vi historierne som indgangsvinkel til en nuanceret diskussion af, hvad man med Johnson-Hanks' ord kunne benævne ,skolegangens fortryllende magt“ (2006). Fælles for historierne er, at de finder sted i lokale, rurale kontekster, hvor uddannelse og skolegang tillægges en vægtig betydning, men hvor der samtidig er stor usikkerhed forbundet med, hvad fremtiden som uddannet kan bringe. Begge drenge tilhører en gruppe unge, for hvem det er muligt, og af hvem det forventes, at de vil færdiggøre en uddannelse, modsat deres bedsteforældre. Skolegangen er dog ikke en udpræget positiv oplevelse for drengene, der gang på gang oplever ydmygelser og nederlag, men som ikke desto mindre opfordres af deres omgivelser til at fortsætte i skolen, selv om det kan forekomme sandsynligt, at den bedste måde at klare sig på for begge drenge ville være at få et stykke jord og blive bønder.

Igennem begge forløb er der således vedvarende håb og tro på, at skolebøgerne på magisk vis kan fungere som portaler til et andet og bedre sted (ibid.). Den fortryllende egenskab, som uddannelse tillægges i udviklingspolitik, er med andre ord også at finde i disse to historier, hvor alle involverede parter synes at være besatte af ideen om uddannelse og af det implicitte løfte om konkrete forbedringer, som uddannelse bærer med sig. Fortryllelsen ser ud til at have ledt begge drenge i en fælde.

Serpell, der skriver om uddannelse i Zambia (1993), kalder dette fænomen for „den moralske fælde“ - en fælde, der indtræder, fordi uddannelsessystemet făr eleverne til at føle sig som fiaskoer, hvis de ikke består deres uddannelse. Ifølge Serpell er problemet strukturelt, fordi der hverken er uddannelsespladser nok (i sekundær skole og på tertiære uddannelsesinstitutioner) eller efterfølgende job, hvilket presser elever ud af uddannelsessystemet som „,dropouts“, ligesom Deus. Ligeledes er problemet moralsk i en meget konkret betydning, idet eleverne ved at droppe ud af skolen bliver antitesen på det moderne uddannelsesprojekt, der stræber efter at skabe oplyste og civiliserede medborgere. Ydermere ligger den moralske fælde i, at eleverne, som Ochom og Deus, kommer til at opleve sig 
selv som fiaskoer, der ,ikke havde hjernen, der skulle til“" for at klare sig i uddannelsessystemet (se også op.cit.10-12).

I Uganda og Tanzania er Serpells fælde umiddelbar at få øje på, også i et makroperspektiv. Der er ikke uddannelsespladser nok til alle, der ønsker at gå videre fra grundskolen, og der er langtfra nok lønnede job til de kandidater, for hvem det lykkes at blive færdige med en sekundær eller tertiær uddannelse. I begge østafrikanske stater er der massiv arbejdsløshed - ikke mindst blandt de veluddannede, som ønsker job, der svarer til deres uddannelsesniveau. Vejen til arbejdsmarkedet er desuden vanskeliggjort af, at indholdet i uddannelsesforløbene ofte ikke matcher den sociale virkelighed eller endog er på så lavt et niveau, at det giver bedre mening at tale om arbejdsløshedsproblematikken ud fra manglen på reelt kvalificeret arbejdskraft (Wedgwood 2005:22). Manglen på job til højtuddannede samt manglende muligheder for honorering af forventningerne til job er derfor medvirkende til en problematisk ,hjerneflugt“ til Sydafrika, Europa og Nordamerika. Langt de fleste elever med sekundær uddannelse og kandidatgrader fra universitetet har dog ikke mulighed for at rejse til udlandet, men bliver hængende i deres hjemegn eller søger lykken i urbane centre og håber - nogle gange i det uendelige - på et job.

Man kan derfor med rimelighed spørge, hvorfor der i Uganda og Tanzania lægges så meget energi og værdi i en skolegang, der - som i Ochom og Deus' tilfælde - i sidste instans viser sig at være en fælde. Her bringer Serpells teori os ikke videre, idet den primært forholder sig til, hvad der sker, når folk er gået i fælden. I et forsøg på at begribe, hvorfor folk fortsat går i fælden, har vi derfor ladet os inspirere af Alfred Gells tanker om fortryllelse (1992) og fælder (1996).

Hvor flere antropologer tidligere har draget metaforiske paralleller mellem skolegang, religion og magi (Pels 1999; Sanders 2001; Johnson-Hanks 2006), gør Gell selve fortryllelsen til sit genstandsfelt med udgangspunkt $i$ en analyse af kunstværker, hvorunder ,fælder“ indtager en fremtrædende plads som et sådant kunstværk. Ifølge Gell lokker og fortryller en fælde sit bytte ved at spille på de forestillinger og tanker om sig selv, som byttet måtte have. Det vil sige, at fælden skaber en attråværdig repræsentation af byttet, som byttet ser sig selv i eller ønsker at se sig selv i (Gell 1996). I samme tråd skriver Willerslev (2007) om yukaghirjægerne i Sibirien, at de lokker elge under jagten ved hjælp af illusion og forførelse. Jægerne imiterer elgenes identitet med lyde, bevægelser og lugte og skaber således et tiltrækkende selvbillede, som elgene ikke kan modstå, hvorfor de forføres og derefter nedlægges af jægerne. Tænker vi på den østafrikanske kontekst, synes skolen at fungere på en lignende måde ved at skabe en illusion om en mulig fremtidig identitet som en skolet person (se også Levinson \& Holland 1996:3), der kan nyde moderne bekvemmeligheder og høj status - en 
illusion, mange gerne ser opfyldt og derfor lader sig lokke og fortrylle af. Som nævnt ovenfor ender fælden for de fleste dog med at klappe i. Ikke fordi illusionen bryder sammen, men tværtimod fordi den fortsætter med at lokke byttet dybere ind i fælden. For Ochom og Deus er det ikke muligt at få det job, de drømmer om, men samtidig er vejen tilbage ud af fælden spærret, fordi de er kommet til at tro på, at identiteten som uddannet lønarbejder er den eneste værdige, hvorfor et liv som bonde ikke kan være tilfredsstillende. Det er således med stor resignation og frustration, at Ochom siger, at han er nødt til at opgive håbet om mere uddannelse og et job og i stedet få et stykke jord at leve af. Deus har det problem, at til trods for at han måske selv har opgivet illusionen om, at uddannelse $\mathrm{i}$ hans tilfælde kan føre til et job, vil slægtninge, venner og naboer blive ved med at tro, at fordi han er uddannet, har han penge og mulighed for at hjælpe dem.

Grunden til, at fælden fungerer, er dog ikke kun, at den lokker ved at fremmane et selvbillede, der er værd at stræbe efter, men også at den på magisk vis „fortryller“. Ifølge Gell har et kunstværk (hvor fælden betragtes som et sådant) evnen til at fortrylle sin beskuer, fordi det er selve resultatet af en teknisk ekspertise, som beskueren ikke selv besidder og ej heller kan forestille sig (Gell 1992: 163). Fortryllelsen består dermed ikke i, at kunstværket i sig selv er smukt eller har et særligt værdifuldt indhold, men snarere i den kunsthåndværksmæssige tilblivelsesproces involveret deri, som ligger ud over beskuerens forestillingsevne og derfor kun kan forklares i magiske termer (op.cit.169). Denne utilgængelighed og symbolske, mentale distance, der er mellem kunstværket og beskueren, gør samtidig, at dets tillagte værdi og magiske egenskaber kan være ude af proportioner med det faktiske indhold og derfor fortryller tilskueren (ibid.).

Hvis man oversætter de tekniske processer involveret $i$ at fremstille et kunstværk til de sociale processer, der er involveret $i$ at skabe en uddannet person, er skolen dermed at betragte som en art social teknologi, der fortryller, fordi dens skabelsesproces ligger ud over forestillingsevnen hos en stor del af befolkningen. Denne utilgængelighed findes på flere planer, først og fremmest $i$ forhold til det konkrete faglige indhold af den undervisning, eleverne modtager i Tanzania og Uganda, som ofte er af så abstrakt og teoretisk karakter, at det for udenforstående kan synes umuligt at forstå, hvorved det ophøjes til noget magisk. Mest tydelig er utilgængelighedsgørelsen i den de facto-hemmeligholdelse af viden (se Meinert 2001, 2009; Kølner 2008), som foregår inden for skolens rammer, hvor undervisningen foregår på engelsk - et sprog, der er uforståeligt for størstedelen af befolkningen. Skolebøger er en mangelvare og låses omhyggeligt ind i skabe eller bæres af læreren, hvilket betyder, at det er svært at få adgang til tekst og dermed svært at bryde læsningens magiske kode. Derudover fungerer fortryllelsen ved, at skoling i høj grad har været utilgængelig for mange i den ældre generation, 
der ikke har et klart begreb om, hvad der foregår inden for skolens mure, og derfor tillægger det magisk værdi. Størstedelen af den ældre generation i Østafrika (såsom Deus' og Ochoms bedsteforældre) kigger således betagede på med en blanding af ærefrygt og hovedrysten, når børnene i skolen synger nationalsang og marcherer, mens flaget hejses, hvorefter de forsvinder ind i skolen, kommer ud efter en årrække og har tilegnet sig færdigheder og en status, der gør, at de kan få institutioners døre, for eksempel i sundhedssystemet, til at gå op på magisk vis. I skoleinstitutionen struktureres tid, rum og krop markant anderledes (Meinert 2009:67ff.) end de gængse hverdagspraksisser omkring landbrug og hushold, som folk har levet med i generationer. I forhold dertil kan skolens praksisser derfor synes mystiske, magiske og fortryllende for dem, der ikke selv har oplevet et klasseværelse indefra, eller som ikke kan tyde bogstaverne og sproget.

I forlængelse deraf vil vi hævde, at fortryllelsen af skolegang er at finde i Tanzania og Uganda, netop fordi det ikke er majoriteten, der har fået skolernes sociale teknologi indlejret i kroppen. Men efterhånden som størstedelen af befolkningen (set over flere generationer) får adgang til uddannelse, affortrylles skolen, i takt med at distancen til det uopnåelige formindskes. Idet alle får lige adgang til skolen, mister den sin eksklusive kraft. I Tanzania kan man således tale om, at affortryllelsen på det lokale plan er sat ind i forhold til grundskolen, som i længere perioder og dermed over flere generationer har været frit tilgængelig for alle. For de fleste tanzaniere tillægges grundskolen derfor ikke længere nogen særlig betydning, og der er ingen særstatus forbundet med at have en afgangseksamen herfra. Nedvurderingen af primær uddannelse blandt befolkningen har dog også rødder i den tidligere socialistiske, tanzaniske uddannelsespolitik, som med uddannelsesreformen i 1967 søgte at ruralisere uddannelsessystemet og gøre grunduddannelsen afsluttende $\mathrm{i}$ et forsøg på at fastholde folk i landdistrikterne. Fra politisk side var der tale om et forsøg på at få flere tanzaniere i skole og øge sammenhængskraften mellem uddannelse og (manuelt) arbejde, men det fik den uintenderede konsekvens, at befolkningen i høj grad betragtede grundskolen som et udklækningssted for fremtidige bønder frem for som en støbeform for moderne medborgere. Med andre ord blev reformen ikke budt velkommen af tanzanierne. De var ikke mere fortryllede af uddannelse, end at de tydeligt kunne se, at de selvsamme politikere i højt betalte stillinger, som forsøgte at overbevise dem om værdien af ,plovens arbejde“ og om, at sekundær uddannelse ikke var værd at stræbe efter, udelukkende selv var sekundært uddannede mennesker (se også Meinert 2003 for en beskrivelse af samme proces i Uganda). Linket mellem primær uddannelse og nedvurderet manuelt arbejde blev dermed grundlagt tidligt i befolkningen og har højst sandsynligt speedet affortryllingsprocessen op sammen med de stigende indskrivningstal efter 1974. I dag fremhæver 
man i Tanzania med navnet på sekundærskolen, som kaldes „shule kamili““, at det først er på dét niveau, man har en „komplet uddannelse“. Grundskolen betragtes med andre ord blot som et nødvendigt afsæt til sekundær skole, der til gengæld ikke har mistet sit magiske skær eller sin eksklusive kraft, idet tilgangen dertil er kraftigt begrænset af høj brugerbetaling, få skoler og høje adgangskrav. Således har Tanzania et af de absolut laveste indskrivningstal for sekundære skoler - ikke kun i Østafrika, men i hele verden (World Economic Forum 2009: 24). Indskrivningen til sekundær skole ligger noget højere i Uganda, hvor der nu også er indført et gratis Universal Secondary Education-program for de dygtigste elever fra grundskolen. Tiden vil vise, om denne åbning for flere elever vil betyde en affortryllelse af sekundærskolen i Uganda.

I Uganda har affortryllelsen af primærskolen fundet sted noget senere end i Tanzania med indførelsen af UPE i 1997. Men affortryllelsen af grundskolen har tilsyneladende haft en lidt anden effekt end i Tanzania, idet indskrivningstallet i Uganda er faldet drastisk (til omkring 50 procent af børn i skolealderen). En del af forklaringen er højst sandsynligt de uformelle skolepenge, som gør, at nogle forældre ikke har råd til at sende deres børn i skole. Politikere i Uganda er oprørte over det dalende indskrivningstal, og i de nationale aviser har debatten raset om, hvem der har ansvaret herfor. Forældre har påpeget, at der efter indførelsen af UPE ikke var meget at sende børn i skole efter, fordi der ikke var ressourcer til rent faktisk at lære børnene at læse, skrive og regne. Derfor holdt mange deres børn hjemme, hvor de var til hjælp for familien.

Folk er med andre ord ikke fuldstændig forblindede af ,trylleriet" og sender ikke deres børn i skole af ren og skær uvidenhed og naivitet. Det er i langt højere grad tale om en „villighed“ til momentant at „lade sig“ forføre - en villighed, der bunder i og drives frem af håbet og troen på, at magien vil indtræffe. Der synes med andre ord at være en høj grad af realisme og bevidsthed omkring fælden og fortryllelsen, som dog stadig trækker, fordi uddannelse er en af de fă ting, der er at håbe på for fremtiden (se også Hagé 2003; Shade 2006). Forældre og unge i Uganda og Tanzania er ganske klar over den latente risiko for, at uddannelse vil være „forgæves“, men påpeger, at „man bliver nødt til at tage chancen“. Desuden er der sund fornuft $i$ at have en uddannelse, såfremt man er heldig nok at få et job efterfølgende. Således får sekundært skoleuddannede statistisk set en langt højere løn end uuddannede, hvis de får et job (Wegdwood 2005:23).

Tiltroen til uddannelse er på trods af svære odds således ikke kun betinget af „fortryllelse“, men også af, at folk ikke ser alternative veje til det gode liv og dermed satser alt håb på uddannelse. Således indgår uddannelse som et kerneelement i de historier, folk fortæller hinanden om familiemedlemmer og bekendte, der har opnået succes, på trods af at skolegangen i mange tilfælde ikke har været 
den udslagsgivende faktor for succesen - set udefra (Kølner 2008). I den sammenhæng er de „gode“ historier, der tager udgangspunkt i succes opnået gennem familierelationer, hårdt arbejde eller rent held, bemærkelsesværdigt fraværende. Den selvforstærkende effekt, som uddannelseshistorierne skaber, bidrager til, at skolegang så at sige har taget monopol på den sociale mobilitet, der ses som den eneste mulige investering, der giver en chance for adgang til arbejde, penge, social status og sikkerhed. Illich sætter fingeren på denne pointe med sin sædvanlige skarphed: „Så overbevisende er den magt, disse institutioner har, at de former, ikke kun vores præferencer, men faktisk vores opfattelse af muligheder“(Illich 1971:1, vores oversættelse)

\section{Utilsigtede heldige bivirkninger}

Det billede, vi hidtil har malet af universel skolegang i Tanzania og Uganda, kan synes pessimistisk, fordi vi har ønsket at vise et modbillede til det glansbillede, uddannelsespolitik ofte maner frem. Det er imidlertid ikke vores hensigt at lægge os direkte i kølvandet på Illichs radikalt kritiske forslag om at afskaffe skolerne. Det ville være forsimplet og passe dårligt med den betydning, vores informanter tillægger skoling. På trods af at udefrakommende kan opfatte skolegang indholds- og udsigtsløs, og på trods af at uddannelse ikke altid har den specifikke effekt, politikere påregner, kan man ikke blot ignorere eller kategorisere den betydning, folk tillægger skoling, som „falsk bevidsthed“. Uddannelse har måske ikke altid et væsentligt indhold, men kan åbne op for forestillinger omkring alternative mulige fremtidige liv. Vi vil derfor nuancere vores kritik af uddannelse i Østafrika ved at se på to piger og deres skoleforløb, der peger på flere dimensioner af skolens betydning.

\section{Naome - Uganda}

Naome var en flittig og vellidt pige, som gik i 7. klasse, da UPE-programmet startede i Uganda i 1997. Hun boede i det samme fattige landområde som Ochom, men kom fra en lidt bedre stillet familie. Naome havde haft polio som barn, og derfor var det ene ben kortere end det andet, men ellers var der ikke meget skrøbeligt over hendes fremtoning og væsen. Naomes far var lærer på en skole i den nærliggende by, hvor han boede med sin andenkone. Naomes mor, som var førstekone, styrede et stort hushold med børn og børnebørn, som alle ernæredes ved familiens lille landbrug, og hovedparten af børnene i Naomes familie gik eller havde gået i skole. Undervisningen i Naomes klasse var meget sporadisk. I mere end halvdelen af timerne dukkede læreren ikke op. Der var to tekstbøger 
til deling imellem 40 elever, og meget undervisning bestod i, at eleverne kopierede lærerens noter fra tavlen. Ofte gik tiden i skolen med at vente tålmodigt, lave morgen- og eftermiddagsparader, synge nationalsang og skolehymne, hejse flag og marchere på stedet. På trods af de ringe læringsvilkår klarede Naome sin afgangseksamen nogenlunde og kom på en sekundær skole i byen, hvor hun fik ganske gode resultater. Med forskellige sponsorer og farens støtte lykkedes det Naome at få en diplomuddannelse i „community development“ på et af de mindre universiteter. Her mødte hun sin nuværende mand, som hun kort efter uddannelsens afslutning giftede sig med og fik to børn med. Hun har endnu ikke fundet et job, som svarer til hendes uddannelse, men fastholder stædigt, at årene på skolebænken har været til stor gavn for hende selv og resten af familien. Som skolepige eskorterede Naome sin mor og andre familiemedlemmer til sundhedsklinikken for at få behandling og til offentlige kontorer, fordi det gav prestige at have et familiemedlem i skoleuniform med som tegn på, at familien var ,uddannet" og moderne (Meinert 2009:145ff.). Da Naome skulle have sit første barn, insisterede hun på at komme på hospitalet for at føde, fordi hun mente, der var en større risiko ved at føde hjemme, da hendes bækken var mindre end normalt på grund af polioen, og hun sagde: „Hvis jeg havde været en landsbypige uden uddannelse, så ville min svigerfamilie ikke have lyttet til mig og hjulpet med penge til at betale hospitalet.“

\section{Rose - Tanzania}

16-årige Rose fra Sengerema var en selverklæret „msoma“ (én, der læser) og en stolt en af slagsen. Med klar og tydelig stemme fortalte hun, at hun som den første i familien var kommet på sekundær skole, og at hun derfor var et foregangseksempel for sine fire yngre søskende. Rose havde altid godt kunnet lide at gå i skole, selv om de første år i grundskolen var præget af hjemsendelser og gråd på grund af skænderier og slagsmål med drengene. Alligevel klarede Rose sig så godt, at hun ved afgangseksamen fik et resultat, der gjorde, at hun kunne vælge imellem tre sekundærskoler i regionen. Valget var dog ikke reelt hendes, men familiens. Som små forretningsdrivende havde Roses forældre ikke råd til at sætte de ekstra penge af, som en kostskoleplads ville koste. Rose blev derfor indskrevet på Sengerema Secondary, da den lå tættest på husstanden, så hun kunne være „day student“. I sekundærskolen klarede Rose sig knap så godt, og hun sukkede tit over de strikse lærere, de mange lektier, præfekterne, der var ivrige efter at straffe de yngre elever, samt ikke mindst, at hun havde svært ved at følge med i nogle af timerne. Ikke desto mindre insisterede Rose på, at tiden på skolen var godt brugt, og at det, hun lærte, var væsentligt. Som eksempel derpå 
kunne Rose fortælle, at hun med nød og næppe havde undgået at blive gift, fordi hun havde lært om den tanzaniske lovgivning i skolen:

$\mathrm{Nu}$ da jeg er en moderne, uddannet person, kan jeg diskutere med min far. Han er nødt til at respektere mine ønsker ... [sidste år] sagde han til mig, at jeg skulle giftes med en dreng fra hans hjemegn, men jeg sagde 'nej!'. Jeg blev ved med at sige nej, nej, nej, selv om han pressede mig hårdt, og jeg sagde til ham 'du kan ikke tvinge mig til at gifte mig med nogen. Det er ulovligt'. Det ved jeg, fordi vi har lært om det i skolen, så jeg viste ham bogen, og så blev han nødt til at afvise drengen!

Derudover mente Rose, at skolegangen var vigtig, fordi den forberedte hende på et moderne liv ved at lære hende om alt fra god hygiejne og fremkaldelse af film til brøndgravning og brug af mikrobølgeovn. Derfor, mente Rose, ville hun være godt rustet, hvis hun skulle opfylde sin drøm om at tage til Mwanza, fă to børn og blive politibetjent. Rose var realistisk nok til at vide, at det ville blive noget nær umuligt at opfylde den drøm, og på spørgsmålet om, hvad hun havde tænkt sig at gøre, hvis drømmen brast, trak hun blot på skuldrene og sagde, at det var o.k. I så fald ville hun overveje at blive syerske eller hjælpe sine forældre med at udvide deres forretning. For som Rose sagde, havde hun jo lært at tælle og føre regnskab og var derfor den bedst kvalificerede i familien til at tage vare på forretningen.

\section{Skoling som en transformativ erfaring}

Selv om skoleprogrammerne og uddannelser som Naomes og Roses ikke har medført alle de forandringer, som politikere og familier har håbet på, betragtes uddannelse stadig som en vigtig erfaring lokalt. Forældre, unge og børn er opmærksomme på og håber på, at skolegang har potentialet til at transformere deres livsbaner. For Naome bliver skoleidentiteten en kompetence, som kan distribueres og bruges i familien i konkrete møder med institutioner, og kommer på denne måde flere til gode. I Roses tilfælde bliver hendes moderne skoleerfaring konverteret til et „våben“, hun kan bruge mod sin fars gifteplaner. Således har skolegangen for Rose netop transformeret hendes livsbane ved at udvide hendes mulighedsfelt, på trods af at meget af det indhold, hun lærer, er ubrugeligt (se også Johnson-Hanks 2006:94).

Skolegang er som regel en årelang serie af det, Grøn (2006) kalder signifikante rutiner. Skolegangens signifikante rutiner i form af praksisser som at synge, marchere, sidde på skolebænken, holde tiden, skrive, svare i kor og blive afstraffet har markante effekter på individet. Skoling bliver en form for kulturel kapi- 
tal (Bourdieu 1986), der arbejdes ind i kroppen og subjektiviteten. Efterhånden som Naome og Rose arbejder sig igennem skolesystemet, tilegner de sig identiteter og moraliteter, der forbindes med at være uddannet og moderne.

Når vi tager dét, børn og unge selv siger, alvorligt - at de lærer noget i skolen, og når vi observerer, hvad der rent faktisk foregår i løbet af en skoledag, bliver det tydeligt, at der foregår en intensiv læring - blot på en anderledes måde end antaget i skoleprogrammer (se også Jackson (1968) om „skjulte læreplaner“ og Willis (1977) om ikke-intenderet læring i skolen). Batesons berømte indsigt, at mennesker ikke kan undgå at kommunikere, ,we cannot not communicate" (1972), kan også tænkes i forhold til læring og erfaring: Vi kan ikke ikke lære. Vi kan ikke stoppe flowet af oplevelser og sansninger af verden, og derfor foregår der altid en form for læring (Meinert 2009:7). Selv om undervisningen kan synes meget begrænset i mange skoler i Østafrika, lærer børn og unge meget - på godt og ondt - blot ved samværet og kommunikationen med hinanden. Mange børn i grundskolen lærer rent faktisk ikke at skrive, læse og regne særligt godt, men alligevel viser store kvantitative surveys, at det gør en forskel for børns sundhed og overlevelse, hvis deres mødre har været blot et par år i skole (se f.eks. Caldwell 1979; Bruns 2003). Det er altså ikke nødvendigvis skrive-, læse- og regnefærdigheder, der udgør den positive effekt af skoling, men det er måske nærmere den identitetsmæssige effekt af at gå i skole, der er værd at bide mærke i (se også Katahoire 1998). Denne effekt relaterer sig til den virkning, det kan have, at være blevet indlemmet i et lokalt og nationalt fællesskab og føle sig set og behandlet som en respektabel medborger i et samfund.

Bourdieus idé om habitus er et af de begreber, der kan bruges til at beskrive, hvordan skoling virker på denne underfundige måde (1986). Den habitus, skolebørn indarbejder og udvikler ved at gå i skole, og den kulturelle kapital, som de får andel i ved at være medlemmer af den nationale institution, skolen udgør, har positive konsekvenser for deres handlekompetence på andre områder i livet. I skolen lærer børn at udleve en særlig institutionel måde at strukturere rum og tid på - i klasselokaler, med timer og frikvarterer. Ved at disciplinere både krop og sjæl transformerer de sig selv til dét, Foucault har kaldt føjelige og produktive medborgere (1977). Ved at repetere, svare i kor og abe efter făr børn i skolerne adgang til „de lærdes“" sprog og identitet (Pels 1999). Vi mener imidlertid ikke (se Levinson \& Holland 1996), at det er tilstrækkeligt at begrebsliggøre skolepraksis som spørgsmål om magt, undertrykkelse og modstand, fordi elever ikke bare passivt modtager eller aktivt gør modstand mod skoling. De tilegner sig disse - tilsyneladende undertrykkende - strukturer for at vinde social anerkendelse og kompetencer til at forfølge deres egne mål. I skoler i Østafrika lærer børn et distinkt sprog og bestemte måder at kommunikere på, som blandt andet 
fremmer særlige måder at stille spørgsmål og svare på (Stambach 2000). Disse måder viser sig at være brugbare i andre institutionelle sammenhænge, fordi de anerkendes som „dannede“ måder at tale og gebærde sig på, som vi har set det med Naome på sundhedsklinikken.

Det er ikke tilfældigt, at de to cases, der viser nogle af de mere positive konsekvenser af uddannelse, har piger i hovedrollen. Der er i vores materiale fra begge lande en tendens til, at piger i højere grad end drenge „får mere ud af“ deres skolegang og anvender deres erfaring på måder, der har større effekt i deres liv. Begge køn befinder sig dog i samme fælde, idet piger på ingen måde har større chance end drengene for at få et godt betalt job efter endt uddannelse (måske snarere tværtimod), men måden, hvorpå håndteringen af fælden og dens indflydelse på de håb, der er bundet op på skolegang, bliver angrebet, er markant forskellig. Drengenes hægen ved ideen om en bestemt type moderne liv synes at efterlade dem fanget i fælden med en gryende oplevelse af desillusion og affortryllelse (som set med Ochum og Deus), mens pigerne tilpasser deres ,forestillingshorisonter" (Crapanzano 2004) til omstændighederne i nuet, hvilket giver dem mulighed for at kravle ud af fælden med håbet $\mathrm{i}$ behold og rester af tryllestøv på hænderne. Dertil er der flere mulige forklaringer, hvoraf én er, at de håb og forestillinger, der er bundet op på uddannelse, er forskellige for de to køn. For pigerne er det små håb om, at skolegangen og den moderne identitet kan forbedre deres liv ved for eksempel at udfri dem af snærende slægtskabsforventninger, mens det for drengene drejer sig om at få et job, så de kan få et moderne liv, men med traditionelle bekvemmeligheder (Kølner 2008). Idet der ikke er høje forventninger til, at piger skal opnå et godt job, har pigerne mulighed for at rejse sig fra fælden og blive husmødre og bønder med oprejst pande, mens det bliver en moralsk nedtur for drengene, til hvem forventningerne er anderledes høje. Pigerne står dermed til at „vinde“ mere i uddannelsesprojektet end drengene. Eller - mere præcist - pigerne står ikke til at ,tabe“ så meget, når fælden klapper i, og det første håb slukkes, når de kommer ud af skolens porte som uddannede arbejdsløse, idet de befinder sig lavere på den sociale rangstige end drengene, hvis „fald“ dermed også er længere, såfremt fælden smækker i. I stedet hægter pigerne sig fast i de positive, små fremskridt, de har gjort via deres skolegang fremskridt, der ikke var helt, som de havde regnet med, men som alligevel ses som forbedringer i forhold til status quo.

\section{Konklusion}

Gennem Gells fortryllelses- og fældeoptik har vi i artiklen forsøgt at tage fat i den universelle og aktuelle fascination, der omgiver uddannelse, og se på den sociale 
dynamik i den fortsatte optimisme, som omgærder skolegang i Østafrika, på trods af at skolens indhold ikke imponerer, og mange elever ikke får de færdigheder, som man ville forvente af en skoleuddannelse.

Nogle politikere vil sikkert hævde, at skoleprogrammerne i Uganda og Tanzania er succeser, hvis succeskriteriet er, at indskrivningstallene er blevet højere, og at der er bygget skoler i alle kroge af de to nationer. Ligeledes kan skoleprogrammerne betegnes som en succes i forhold til deres gavnlige effekt på børns sundhed og overlevelse, om end den nærmere logik og indbyggede sammenhængskraft deri langtfra er kortlagt. Men hvis man ser en smule grundigere på kvaliteten og udbyttet af uddannelse, er der grund til at mane til besindelse og overveje, om de store, gratis skoleprogrammer nødvendigvis er vejen frem for alle udviklingslande. Hvis der ikke er ressourcer til at drive en skole, der kan værdsættes lokalt, og som er tilgængelig for alle, går den magiske luft af ballonen, og børn og unge risikerer at blive tabt på gulvet undervejs i processen. Ikke mindst hvis man med disse UPE-programmer får ødelagt den paradoksale positive virkning, der er i, at skoling er noget eksklusivt. Fortryllelse består kun så længe, at der er nogen, der holder noget hemmeligt af en vis kvalitet. Men når alle får adgang til det hemmelige, som viser sig at være af forholdsvis dårlig kvalitet, fordamper noget af fortryllelsen, som dermed ikke længere kan bidrage til ideen om en særlig attråværdig skolet identitet. Med gratis skoleprogrammer bliver man nødt til at investere massive ressourcer i skoleundervisningen for at få den op på et tilstrækkeligt niveau og bevare lidt af fortidens glans. Samtidig må en uddannelsespolitik støttes op af en realistisk socialpolitik, der medtænker beskæftigelsesmuligheder - ikke kun for de kandidater, der bliver færdige i uddannelsessystemet og som på nuværende tidspunkt ikke kan opsluges af det østafrikanske arbejdsmarked - men også for unge som Deus og Ochom, der dropper ud af skolen og dermed rammes dobbelt hårdt. I kraft af deres skolefrafald bliver de ikke kun antitesen på medborgerskabets ideal om og forpligtelse til at være en respektabel del af fællesskabet og nationen, men mister samtidig mulighederne for det liv, de og andre havde håbet på.

Vi plæderer ikke som Illich (1971) for at afskaffe skolen, men håber på mere kritisk refleksion over skoleprogrammers ideer og dynamikker i praksis. Elever får på gådefuld vis noget ud af skolen, selv om undervisningskvaliteten er tvivlsom set udefra. For at tage dette alvorligt, som vi mener antropologisk uddannelsesforskning bør, lægger vi os op ad Stambachs forståelse, idet hun argumenterer for, at ,skolegangens betydning ligger i, hvad skolen betyder lokalt ikke i dens objektive indhold“" (Stambach 1998:188). Som vi har set i artiklen og de enkelte cases, har skoleundervisningen måske ikke altid et væsentligt indhold, med et etic perspektiv, men skolen åbner for elevernes forestillinger om- 
kring alternative mulige „fremtidige liv“ og kan være med til at åbne døre til institutioner, som ellers ville være forblevet lukkede. Skolegang kan på den måde, efter elevernes eget udsagn, have en decideret positiv betydning, men ikke nødvendigvis den betydning og konsekvens, som planlæggerne bag skoleprogrammerne havde regnet med.

Selv om UPE i Østafrika på nogle områder er blevet affortryllet, fordi alle har fået adgang til skolen, er der således stadig fortryllende aspekter i uddannelse, fordi ingen helt kan forudsige, hvad skolegang vil betyde for den enkelte, og hvilke konsekvenser den kan få på andre niveauer.

\section{Noter}

Tak til Rådet for Udviklingsforskning, Forskningsrådet for Kultur og Kommunikation og Højgaard Fonden for bevillinger, der har gjort feltarbejde og forskning muligt".

1. Skolesystemerne i Tanzania og Uganda er på visse punkter forskellige, men består i store træk af syv års grundskole (primary school), fire års sekundær skole (secondary school, O-level), hvorefter eksaminer afgør, hvorvidt den studerende kan gå videre til A-levels, som tager to år. Denne eksamen er adgangsgivende til universitetet og andre tertiære uddannelsesinstitutioner.

2. I Uganda etablerede britiske missionærer de første bibelskoler i 1877 i det centrale Buganda (Ssekamwa 1997:25-9), og herfra udbredte missionærerne skoler i andre dele af Uganda. I Tanzania blev de første skoler startet af tyske missionærer i 1840'erne (Buchert 1994:15; Austen 1968:57).

3. Oprindeligt specificerede skolepolitikken i Uganda, at en familie maksimalt kunne sende fire børn til gratis skolegang. Men interessen fra familierne var så stor, at folk fandt på forskellige måder at omgå reglen på, eksempelvis ved at sende fire børn til en skole og to til en anden. Denne form for snyd kunne lade sig gøre, fordi der ikke var nogen central registrering af forældre og deres børn (og børnenes alder). Regeringen opgav derfor begrænsningen på fire børn og gjorde adgangen fri for alle børn.

4. Begrebet ,kritiske begivenheder“ har vi fra Veena Das, der beskriver disse som ,,perioder i tiden, hvor store transformationer opstår i rum, hvorved folks liv propelleres ind i nye og uforudsete terræner. Efter sådanne begivenheder genereres nye handlingsmuligheder som redefinerer traditionelle kategorier" (1995:5-6, vores oversættelse).

Nøgleord: Skolegang, fortryllelse, håb, fælde, Uganda, Tanzania.

\section{Litteratur}

Austen, Ralph A.

1968 Northwest Tanzania under German and British Rule. Colonial Policy and Tribal

Politics, 1889-1939. London: Yale University Press

Bateson, Gregory

1972 Steps to an Ecology of Mind. New York: Chandler Publishing Company. 
Bourdieu, Pierre

1986 The Forms of Capital. I: J.G. Richardson (ed.): Handbook of Theory and Research for a Sociology of Education. Westport: Greenwood Press.

Bruns, Barbara

2003 Achieving Universal Primary Education by 2015: A Chance for Every Child.

Washington DC: World Bank.

Buchert, Lene

1994 Education in the Development of Tanzania 1919-1990. London: James Currey Ltd.

Crapanzano, Vincent

2004 Imaginative Horizons. An Essay in Literary-philosophical Anthropology. Chicago: University of Chicago Press.

Caldwell, Jack

1979 Education as a Factor in Mortality Decline: An Examination of Nigerian Data.

Population Studies 33:395-413.

Das, Veena

1995 Critical Events. An Anthropological Perspective on Contemporary India. Oxford $\&$ New York: Oxford University Press.

Dore, Ronald

1976 The Diploma Disease: Education, Qualification and Development. Berkeley: University of California Press.

Foucault, Michel

1977 Discipline and Punish. The Birth of the Prison. New York: Vintage Books.

Gell, Alfred

1992 The technology of Enchantment and the Enchantment of Technology. In the Art of Anthropology. London \& New Brunswick, NJ: The Athlone Press.

1996 Vogel's Net: Traps as Artwork and Artwork as Traps. Journal of Material Culture $1: 15-38$.

Grøn, Lone

2006 Krop og hverdag i forandring. Sundhedsfremme og forebyggelse i institution og hverdagsliv. Vejle Amt: Sundhedsforvaltningen.

Hagé, Ghassan

2003 Against Paranoid Nationalism. Searching for Hope in a Shrinking Society.

London: The Merlin Press Ltd.

Hansen, Holger Bernt

1984 Mission, Church and State in a Colonial Setting. Uganda 1890-1925. London:

Heineman.

Ivan Illich

1971 Deschooling Society. New York: Harper and Row.

Jackson, Philip W.

1968 Life in Classrooms. New York: University of Chicago Press.

Johnson-Hanks, Jennifer

2006 Uncertain Honour. Modern Motherhood in an African Crisis. Chicago: University of Chicago Press. 
Katahoire, Anne

1998 Education for Life: Mothers' Schooling and Children's Survival in Eastern

Uganda. Ph.d.-afhandling. Institut for Antropologi, Københavns Universitet.

Kølner, Mette

2008 "In Tanzania We Say that Development is a Long Journey, but it all Starts with Education". Engaging the Modern through Gendered Experiences of Schooling in Sengerema. Kandidatspeciale. Afdeling for Antropologi og Etnografi, Århus Universitet.

Lasibille, Gerard et al.

2000 Expansion of Private Secondary Education: Lessons from Recent Experience in Tanzania. Comparative Education Review 44(1):1-28.

Levinson, Bradley \& Dorothy Holland

1996 The Cultural Production of the Educated Person: An Introduction. I: B. Levinson, D.E. Foley \& D. Holland (eds.): The Cultural Production of the Educated Person. Critical Etnographies of Schooling and Local Practices. Albany: State University of New York Press.

Meinert, Lotte

2001 The Quest for a Good Life. Health and Education among Children in Eastern Uganda. Ph.d.-afhandling. Institut for Antropologi, Københavns Universitet.

2003 Sweet and Bitter Places: The Politics of Schoolchildren's Orientation in Rural Uganda. I: K.F. Olwig \& E. Gulløv (eds.): Children's Places: Cross-cultural Perspectives. London: Routledge.

2009 Hopes in Friction. Schooling, Health and Everyday Life in Uganda. Charlotte: Information Age Publishing.

Pels, Peter

1999 A Politics of Presence: Contacts between Missionaries and Waluguru in Late Colonial Tanganyika. Singapore: Harwood Academic Publishers.

Sanders, Todd

2001 Save our Skins. Structural Adjustment, Morality and the Occult in Tanzania.

I: H. Moore \& T. Sanders (eds.): Magical Interpretations, Material Realities.

Modernity, Witchcraft and the Occult in Post-colonial Africa. London: Routledge.

Serpell, Robert

1993 The Significance of Schooling. Life-journeys in an African Society. Cambridge:

Cambridge University Press.

Shade, Patrick

2006 Educating Hopes. Studies in Philosophy and Education 25(3):191-225.

Shephard, Jessica

2009 Education in Tanzania: A Series of Near-Misses. Mail\&GuardianOnline. http: //www.mg.co.za.

Stambach, Amy

1998 "Education is my Husband": Marriage, Gender and Reproduction in Northern Tanzania. I: M.N. Bloch et al. (eds.): Women and Education in Sub-Saharan Africa: Power, Opportunities, and Constraints. Boulder: Lynne Rienner.

Stambach, Amy

2000 Lessons from Mount Kilimanjaro. Schooling, Community and Gender in East Africa. London: Routledge. 
Ssekamwa, J.C.

1997 History and Development of Education in Uganda. Kampala: Fountain Publishers.

Vilby, Knud

2005 Uafhængig? Afrikanske udfordringer. Helsingør: Forlaget Per Kofod.

Wedgwood, Ruth

2005 Post-basic Education and Poverty in Tanzania. Working Paper Series 1. Edinburgh: Centre of African Studies.

Willerslev, Rane

2007 Soul Hunters. Hunting, Animism and Personhood among the Siberian Yukaghirs. Berkeley, LA, \& London: University of California Press.

Willis, Paul

1977 Learning to Labour: How Working Class Kids get Working Class Jobs. Westmead: Saxon House.

The World Economic Forum

2009 The Africa Competitiveness Report 2009. Geneva: The World Economic Forum.

\section{Hjemmesider}

http://www.2015.dk

http://www.moe.go.tz/policy_issues.html 